\title{
Nrf2 inhibitor brusatol ameliorates cecal ligation and puncture-induced lung injury in rats via anti-inflammation and anti-oxidative stress
}

\section{Nrf2 inhibitörü brusatol, sıçanlarda anti-inflamasyon ve anti-oksidatif stres yoluyla çekal ligasyonu ve delinmeye bağlı akciğer hasarını iyileștirir}

\section{Ersen ERASLAN ${ }^{1}$, Ayhan TANYELi ${ }^{2}$, Mustafa Can GÜLER ${ }^{2}$, Fazile Nur EKINCI-AKDEMIR ${ }^{3}$, Tuncer NACAR ${ }^{2}$, Ömer TOPDAĞ ${ }^{4}$, Elif POLAT ${ }^{5}$}

\section{ABSTRACT}

Objective: The aim of this study is to investigate the possible beneficial effects of brusatol on lung injury caused by cecal ligation and puncture (CLP) model in rats.

Methods: In this study, 32 Sprague Dawley male rats were divided into 4 random groups. The groups were programmed as group 1 (sham), group 2 (CLP), group 3 (DMSO), and group $4(0.5 \mathrm{mg} / \mathrm{ml}$ brusatol). In group 1 , a midline vertical incision was applied to the abdominal region and closed again without forming a CLP model. Group 2 performed CLP for 18 hours. In group 3, 1\% DMSO was administered intraperitoneally $0.3 \mathrm{ml}$ once every two days for 10 days. The last application was made 30 minutes before CLP. In group 4, brusatol was administered intraperitoneally at $0.5 \mathrm{mg} / \mathrm{ml}$ once every two days for 10 days. The last application was made 30 minutes before CLP. After CLP was over, the rats were sacrificed and lung tissues were removed.

Results: MDA, MPO, OSI, TOS, TNF- $\alpha$ and IL-1B values increased significantly in groups 2 and 3 compared to group 1, while SOD and TAS values decreased. Unlike the

\section{ÖZET}

Amaç: Bu çalıșmanın amacı, brusatolün sıçanlarda çekal ligasyon ve delinme (CLD) modelinin neden olduğu akciğer hasarı üzerine olası yararlı etkilerinin incelenmesidir.

Yöntem: Bu çalıșmada 32 adet Sprague Dawley erkek sıçan 4 rastgele gruba ayrıldı. Gruplar; grup 1 (sham), grup 2 (CLD), grup 3 (DMSO) ve grup 4 (0.5 $\mathrm{mg} / \mathrm{ml}$ brusatol) olarak programlandı. Grup 1'de karın bölgesine orta hatta dikey insizyon uygulandı ve CLD modeli olușturmadan tekrar kapatıldı. Grup 2'de 18 saat CLD yapıldı. Grup 3'e, \%1 DMSO 10 gün boyunca iki günde bir periton içine $0.3 \mathrm{ml}$ uygulandı. Son uygulama CLD'den 30 dakika önce yapıldı. Grup 4'e brusatol 10 gün boyunca iki günde bir periton içine $0.5 \mathrm{mg} / \mathrm{ml}$ olarak uygulandı. Son uygulama CLD'den 30 dakika önce yapıldı. CLD bittikten sonra sıçanlar sakrifiye edildi ve akciğer dokuları çıkarıldı.

Bulgular: MDA, MPO, OSI, TOS, TNF-a ve IL-1B değerleri grup 2 ve 3'te, grup 1'e kıyasla anlaml derecede yükselirken, SOD ve TAS değerleri azaldı. Antioksidan enzim aktivitesindeki artıșın aksine; MDA

'Yozgat Bozok University, Faculty of Medicine, Department of Physiology, Yozgat

${ }^{2}$ Atatürk University, Faculty of Medicine, Department of Physiology, Erzurum

${ }^{3}$ Ağr İbrahim Çeçen University, High School of Health, Department of Nutrition and Dietetics, Ağrı

${ }^{4}$ Atatürk University, Faculty of Medicine, Department of Internal Medicine, Erzurum

${ }^{5}$ Atatürk University, Faculty of Medicine, Department of Biochemistry, Erzurum

İletişim / Corresponding Author : Ersen ERASLAN

Yozgat Bozok Üniversitesi Tip Fakültesi Fizyoloji AD. Kat: 366200 Yozgat - Türkiye

E-posta / E-mail : ersen.eraslan@bozok.edu.tr

Geliş Tarihi / Received : 07.04.2020 Kabul Tarihi/Accepted : 21.10.2020

DOI ID : 10.5505/TurkHijyen.2020.75232

Eraslan E, Tanyeli A, Güler MC, Ekinci-Akdemir FN, Nacar T, Topdağı Ö, Polat E. Nrf2 inhibitor brusatol ameliorates cecal ligation and puncture-induced lung injury in rats via anti-inflammation and anti-oxidative stress. Turk Hij Den Biyol Derg, 2020; 77(4): 467-476 
increase in antioxidant enzyme activity; MDA level, MPO activity, TOS, OSI, TNF- $\alpha$ and IL-1B values decreased significantly in group 4 compared to groups 2 and 3 .

Conclusion: As a result, brusatol may play an effective role against CLD-induced lung injury in rats.

Key Words: Brusatol, oxidative stress, cytokine, cecal ligation and puncture, lung seviyesi, MPO aktivitesi, TOS, OSI, TNF-a ve IL-1B değerleri grup 4'te grup 2 ve 3'e göre önemli ölçüde azaldı.

Sonuç: Sıçanlarda CLD kaynaklı akciğer hasarına karșı brusatol etkin rol oynayabilir.

Anahtar Kelimeler: Brusatol, oksidatif stres, sitokin, çekal ligasyon ve delinme, akciğer

\section{INTRODUCTION}

Sepsis is a complex and multifactorial disease which often causes morbidity and mortality after surgery, trauma, and burns. If it is not controlled, it threatens life by leading to multiple organ failure and even shock $(1,2)$. Lungs are believed to be the first and mostly affected organ due to intraabdominal sepsis (3). Sepsis studies show that excessive proinflammatory cytokine production causes severe acute lung injury (ALI) $(4,5)$. Infiltration of inflammatory cells into the lung is a main characteristic property in the ALI pathogenesis $(6,7)$. Reactive oxygen species (ROS) cause peroxidation of proteins and lipids, activation of transcriptional factors and nucleic acid injury which may cause lung damage (8).

Brusatol (BRU) is a quassinoid obtained from Brucea species. Its effects were investigated in various in vivo and in vitro research models (911). BRU is an inhibitor of nuclear factor erythroid derivative 2 (Nrf2) (12) and its positive effects have been reported in various cancers such as pancreas and lung cancers $(13,14)$. It has also been found to be effective in various intracellular signaling pathways $(11,15)$.

In present study, we aimed to evaluate the effects of BRU on lung tissue by using a cecal ligation and puncture (CLP) model (9) similar to human septic patients with metabolic and hemodynamic properties.

\section{MATERIAL and METHOD}

\section{Ethical Approval and Animals}

Current study was admitted by Atatürk University Experimental Animal Ethics Committee (Protocol no: 28.03.2019-58). The experimental study was performed at Atatürk University Experimental Animals Research and Application Center using healthy Sprague Dawley male rats weighing 230-260 g, procured by Atatürk University Experimental Animal Research and Application Center. Rats were placed in cages in laboratory mediums such as 12 hours of light, 12 hours of darkness, humidity of $55 \%$ and $25^{\circ} \mathrm{C}$ mean temperature. They were fed with standard rat feed, and provided drinking water. The rats were deprived of food 12 hours before the experiment, but were allowed to drink water.

\section{Experimental Animals and Experimental Design}

In this study, 32 healthy Sprague Dawley male rats were used. The rats were randomly assigned to 4 groups. The formation of groups and the applications were as follows. Group 1 (Sham group, $n=8$ ): Abdominal area was opened with a $2 \mathrm{~cm}$ incision to attain peritoneum and then closed with a 3.0 silk suture without any procedure. Group 2 (CLP group, 
$\mathrm{n}=8)$ : Creation of the CLP model: The abdominal area was opened with a $2 \mathrm{~cm}$ incision, and the cecum was isolated by reaching the peritoneum. Before piercing the ileocecal valve with an 18-gauge needle (4 holes), it was tied up to $2 \mathrm{~cm}$ distally. After the cecum was stepped back, the abdomen was sutured with a 3.0 silk suture. Group 3 (DMSO group, $n=8$ ): $1 \%$ DMSO was administered intraperitoneally $0.3 \mathrm{ml}$ once every two days for 10 days and the last application was applied 30 minutes before the CLP model was performed. Group 4 (0.5 mg/ml BRU group, $n=8)$ : BRU was given intraperitoneally $0.5 \mathrm{mg} / \mathrm{ml}$ every second days for 10 days, as described previously (16) and the last application was administered 30 minutes before the CLP model was performed. In the all groups, the abdominal region was washed with povidone-iodine after being shaved. Analgesic lidocaine solution was applied to the suture areas to remove the error margin that might be caused by pain stress. The rats were fasted postoperatively but were allowed access to drinking water.

\section{Biochemical Analysis}

The samples were weighed for $100 \mathrm{mg}$ and homogenized with $2 \mathrm{~mL}$ of phosphate buffer. Homogenized samples were centrifuged at $5000 \mathrm{rpm}$ for 20 minutes at $+4{ }^{\circ} \mathrm{C}$. Then, the supernatants were carefully placed to microcentrifuge tubes and maintained at $-80{ }^{\circ} \mathrm{C}$. The principle of measurement of MDA, as a result of lipid peroxidation, is based on measuring the absorbance at $532 \mathrm{~nm}$ of the pink color compound formed as a result of MDA reaction and thiobarbituric acid (17). TAS and TOS values were determined using ELISA kits (Rel Assay Diagnostics, Gaziantep, Turkey). TOS to TAS ratio was admitted as OSI. Measurement of OSI value was as follows:

OSI $=(\operatorname{TOS}(\mu \mathrm{mol} / \mathrm{L})) /(\operatorname{TAS}(\mathrm{mmol} / \mathrm{L})) \times 10$

OSI was preferred as another indicant for oxidative stress. It has been proposed that OSI may demonstrate oxidative status more correctly than TOS (18). The activity of MPO measurement depends on kinetic measurement of absorbance which has a $460 \mathrm{~nm}$ wavelength of yellowish-orange colored complex as due to action of o-dianisidine with MPO (oxidation) in the presence of hydrogen peroxide (19). The xanthine oxidase enzyme catalyzes the formation of uric acid from xanthine. In the end, consisted superoxide generates hydrogen peroxide and molecular oxygen via superoxide dismutase (SOD) enzyme. And also superoxide and tetrazolium react together to create a formazan dye in cases where SOD effect is inadequate and the act ability of SOD is determined with reference to this reaction's inhibition degree (20).

TNF- $\alpha$ and IL-1B levels in the lung homogenate were measured through commercial ELISA kits (Elabscience, Wuhan, China) using an ELISA reader (BioTEK Powerwave XS Winooski, UK). The entire experimental procedure was performed according to the manufacturer's working protocol.

\section{Statistical analysis}

Biochemical parameters results were analyzed using a statistical analysis program. One-way ANOVA test was preferred for this purpose. Then, Tukey test was performed for group comparisons. The results were demonstrated as mean \pm standard deviation (SD). $P$ values $<0.05$ were considered significant.

\section{RESULTS}

\section{Effect of Brusatol Pretreatment on The Lung Tissues Levels of Oxidative Stress}

When TOS and OSI levels were evaluated, it was found that these levels increased significantly in CLP and DMSO groups compared to sham control group. Same values significantly decreased in BRU group compared to CLP and DMSO groups (Table $1, p<0.05$ ). It was determined that TAS value was significantly decreased in CLP and DMSO groups compared to sham group. But it was significantly increased in BRU group compared to CLP and DMSO groups (Table 1, $\mathrm{p}<0.05$ ). 
Table 1. TAS, TOS and OSI levels of Brusatol in CLP-induced sepsis in rats

\begin{tabular}{|l|c|c|c|}
\hline & TAS $(\mathrm{mmol} / \mathrm{L})$ & TOS $(\mu \mathrm{mol} / \mathrm{L})$ & OSI \\
\hline Sham & $0,79 \pm 0,97$ & $6,34 \pm 0,62$ & $0,80 \pm 0,10$ \\
\hline CLP & $0,34 \pm 0,41^{\mathrm{a}}$ & $10,28 \pm 1,15^{\mathrm{a}}$ & $3,02 \pm 0,48^{\mathrm{a}}$ \\
\hline DMSO & $0,33 \pm 0,03^{\mathrm{b}}$ & $10,34 \pm 1,11^{\mathrm{b}}$ & $3,15 \pm 0,53^{\mathrm{b}}$ \\
\hline BRU & $0,77 \pm 0,04^{\mathrm{b}}$ & $6,75 \pm 0,80^{\mathrm{b}}$ & $0,87 \pm 0,12^{\mathrm{b}}$ \\
\hline
\end{tabular}

Results were expressed as mean \pm SD.

$\mathrm{n}=8$ for each group.

ap $<0.05$ compared with sham group (C).

$\mathrm{bp}<0.05$ compared with CLP and CLP+DMSO groups.

SOD activity decreased significantly in CLP and DMSO groups compared to sham group. On the other side in BRU group there was a significant increase in SOD activity compared to CLP and DMSO groups (Fig. $1 \mathrm{a}, \mathrm{p}<0.05)$. In addition, MPO activity and MDA levels were significantly higher in CLP and DMSO groups compared to sham group. But decreased in BRU group compared to CLP and DMSO groups (Fig. 1b and 1c, $p<0.05)$. a

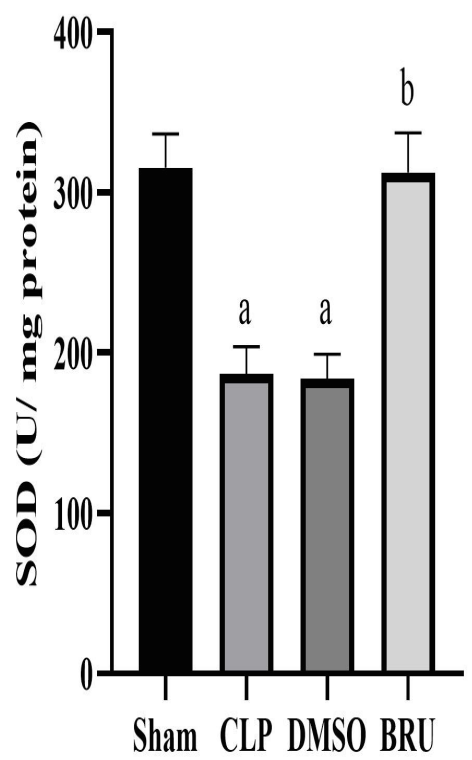

b

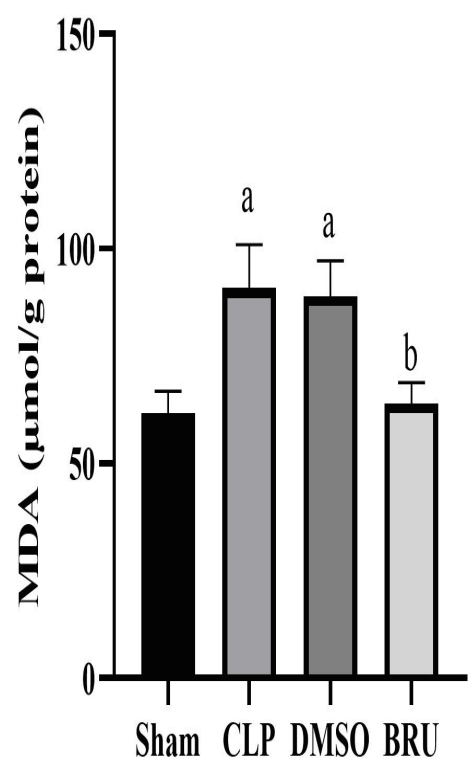

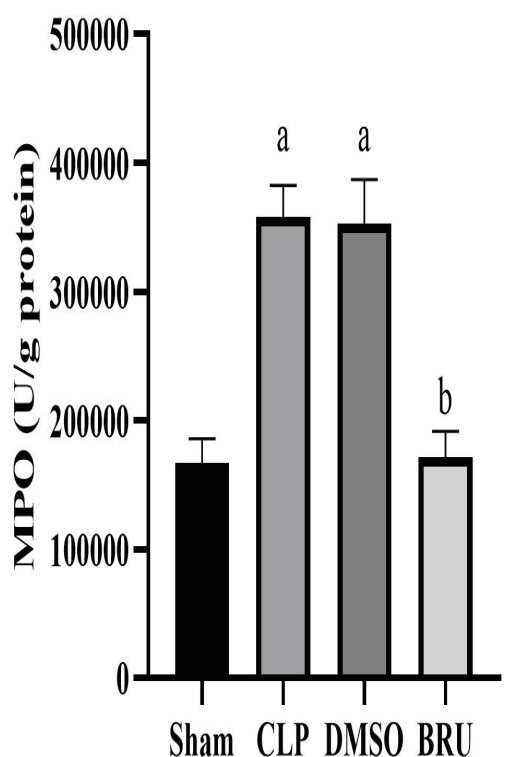

Figure 1. Effect of BRU (0.5 mg/ml every second days for 10 days i.p. $)$ in sepsis models by CLP-induced in rats. (a) SOD levels, (b) MDA levels and (c) MPO levels.

Results were expressed as mean \pm SD.

$\mathrm{n}=8$ for each group.

ap $<0.05$ compared with sham group.

$\mathrm{bp}<0.05$ compared with CLP and DMSO groups 
Effect of Brusatol on Pro-inflammatory Cytokines

elevated compared to sham group, whereas in BRU

When TNF- $\alpha$ and IL-1B levels were analyzed, group these values were significantly decreased CLP and DMSO groups were found to be significantly compared to CLP and DMSO groups (Fig. 2, $\mathrm{p}<0.05$ ).

a

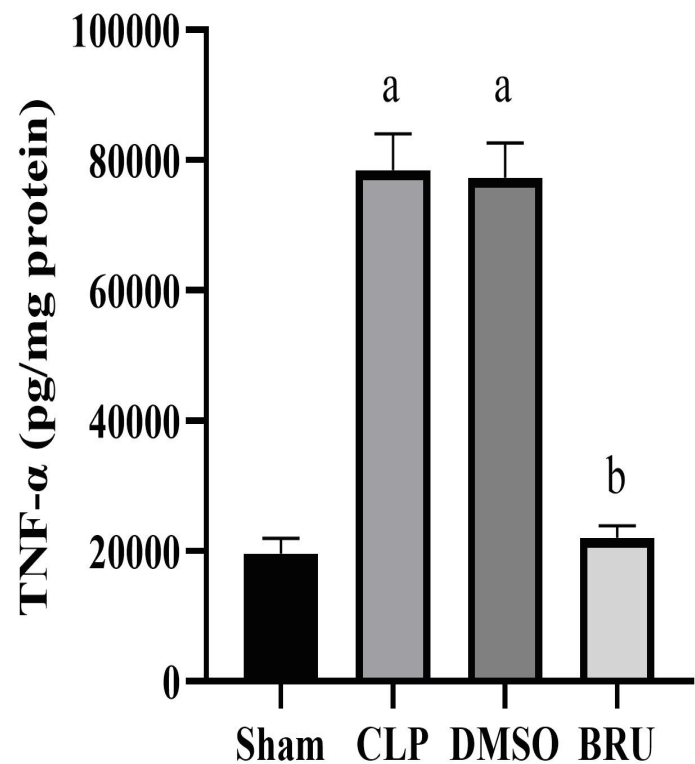

b

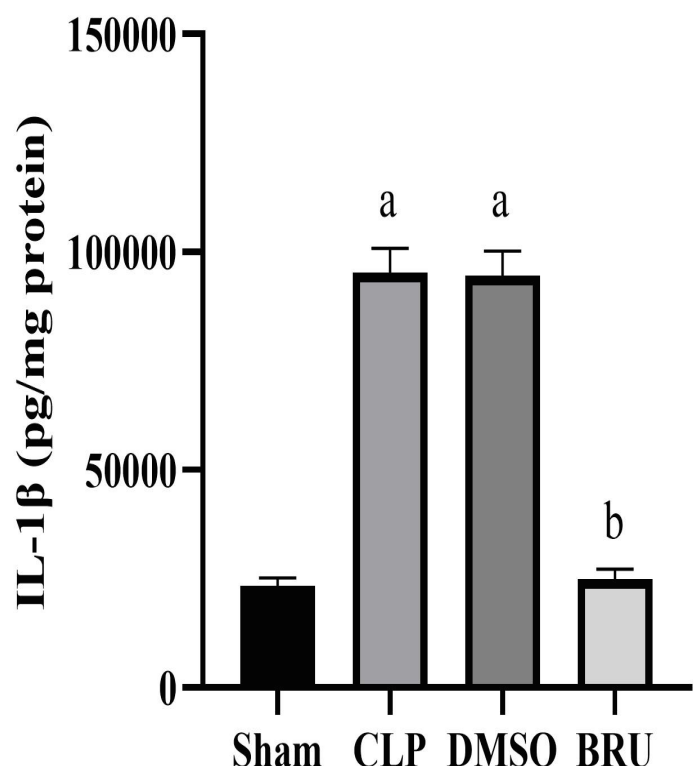

Figure 2. Effect of BRU (0.5 mg/ml every second days for 10 days i.p.) on different cytokines levels in CLP-induced sepsis rats.

(a) TNF-a levels and

(b) IL-1B levels.

Results were expressed as mean \pm SD.

$\mathrm{n}=8$ for each group.

ap $<0.05$ compared with sham group.

$\mathrm{bp}<0.05$ compared with CLP and DMSO groups.

\section{DISCUSSION}

Sepsis is the most common cause of death in hospitalized patients, resulting in millions of deaths each year (21). Organ failure is one of the most common sepsis complications, and the lung is the most easily damaged organ in the sepsis process (22).
In more or less $50 \%$ of severe sepsis cases, ALI and its more dangerous form, acute respiratory distress syndrome (ARDS) occurs $(23,24)$. Sepsis related morbidity/mortality takes place due to multiple organ injury and dysfunction (most commonly causes ALI/ ARDS) (25-28). In the injury pathogenesis and repair process of ALI, inflammatory response has a main role 
(29). It has been shown in numerous clinical studies that proinflammatory cytokines, especially TNF- $\alpha$, IL-1B and IL- 6 participate in early development of ALI (30). In experimental and clinical researchs it has been demonstrated that harmful tissue conditions such as sepsis is sensed by monocytes and macrophages which take role in cytokine secretion (IL-1, TNF-a, etc.) $(31,32)$. A certain part of CLP sepsis pathophysiology is composed of neutrophil accumulation and degranulation $(33,34)$. Neutrophil cytoplasmic granules include MPO as a main content and so, MPO activity is accepted as a pulmonary neutrophil accumulation index (35). MDA is an end product of lipid peroxidation which causes cell damage by membrane polymerization and cross linking induction (36). When polyunsaturated fatty acids are oxidized, MDA occurs and it is an indicator for ROS damage (37).

SOD performs as an antioxidant agent by catalyzing superoxide free radical conversion into oxygen molecule and hydrogen peroxide. SOD and so on antioxidant agents neutralize free radicals and prevent tissues (38). Reduction in antioxidant amounts and increase in ROS production result in favor of oxidative stress when the oxidative-antioxidative balance is evaluated (39). If the immune system is triggered to be activated, free radical releasing is observed and this leads to lipid, protein and DNA peroxidation. Furthermore, macrophage-induced ROS production causes injury in lung tissue endothelium and ARDS (40). Demirbilek et al. (41) indicated that levels of glutathione peroxidase (GSH-Px), SOD and catalase (CAT) reduced in lung tissue during CLPinduced sepsis.

When compared to other models, it has been observed that CLP model supports much more the nature and course of clinical sepsis $(42,43)$. The dominant animal model of intraabdominal sepsis is rodent CLP (44).

Many BRU-related studies are available in the literature supporting the results of present study.
In this study, reduction of IL-1B and TNF- $a$ levels in septic rats by BRU suggests that BRU alleviated CLPinduced ALI. BRU has been shown to be a potent antitumor agent in the colorectal cancer model in mice (45). BRU has been shown to inhibit amyloidinduced neurotoxicity and decrease ROS in U-251 cells (46). BRU has been shown to normalize glucose intolerance due to high fat diet in C57BL/ 6 mice and to have anti-inflammatory properties (47). BRU has been reported to improve the experimental colitis model in rats by decreasing IL- $1 B$ and TNF- $a$ levels and by increasing SOD, GSH and CAT levels (48). BRU has been shown to inhibit the response of cultured beta cells to proinflammatory cytokines in vitro (49). In another study, it was reported that BRU reduced TNF- $\alpha$ and IL-1B levels against chronic obstructive pulmonary disease-like inflammation in the mouse model (9). In parallel with these studies, in this study, antioxidant and anti-inflammatory properties of BRU have been shown in CLP-induced sepsis model in rats. In the CLP group, TAS and SOD decreased while MDA, MPO, TNF- $a$, IL-1B, TOS, OSI levels were increased compared to sham control group and BRU treatment reversed these levels compared to CLP and DMSO groups.

We investigated oxidative stress in lung tissue to find the potential protective mechanisms BRU against CLP-induced lung injury. It was observed that oxidative stress related parameters decreased with BRU.

To perform effective changes in sepsis clinical management, septic organ damage pathogenesis should be understood to develop better therapeutic strategies. It is clearly observed in sepsis studies that inflammation, oxidative stress suppression can provide significant contributions to sepsis treatment. In current study inflammatory response and oxidative stress pathways were diminished by BRU and this may be an important step in the treatment of sepsis. 


\section{CONCLUSION}

BRU provides a protection against lung injury by CLP-induced sepsis with its antioxidant and antiinflammatory effects. Treatment with BRU reduces lung damage in rats exposed to CLP-induced sepsis model. Moreover, further researches are necessary to explain the other protective mechanisms in lung tissue damage induced by sepsis.

\section{ACKNOWLEDGEMENTS}

We would like to thank all participants for contributing in the present survey and also thank to Kardelen Erdoğan and Yaylagülü Yaman, undergraduates of Atatürk University Nursing Faculty, for their effort, help and support during the experiment.

\section{REFERENCES}

1. Russell JA. Management of sepsis. N Engl J Med. 2006;355(16):1699-713.

2. Nemzek JA, Hugunin KM, Opp MR. Modeling sepsis in the laboratory: merging sound science with animal well-being. Comp Med. 2008;58(2):120-8.

3. Babayigit H, Kucuk C, Sozuer E, Yazici C, Kose K, Akgun $\mathrm{H}$. Protective effect of beta-glucan on lung injury after cecal ligation and puncture in rats. Intensive Care Med. 2005;31(6):865-70.

4. Yang L, Li D, Zhuo Y, Zhang S, Wang X, Gao H. Protective Role of Liriodendrin in Sepsis-Induced Acute Lung Injury. Inflammation. 2016;39(5):180513.
5. Zhai Y, Zhou X, Dai Q, Fan Y, Huang X. Hydrogenrich saline ameliorates lung injury associated with cecal ligation and puncture-induced sepsis in rats. Exp Mol Pathol. 2015;98(2):268-76.

6. Abraham E. Neutrophils and acute lung injury. Critical care medicine. 2003;31(4 Suppl):S195-9.

7. Ayhan Tanyeli DGE. The Antioxidant and Antiinflammatory Effects of Alliin on Cecal Ligation and Puncture (CLP)-Induced Lung Injury. TJOS Science. 2019;4(2):46-59.

8. Suliman HB, Carraway MS, Piantadosi CA. Postlipopolysaccharide oxidative damage of mitochondrial DNA. Am J Respir Crit Care Med. 2003;167(4):570-9. 
9. Tang W, Xie J, Xu S, Lv H, Lin M, Yuan S, et al. Novel nitric oxide-releasing derivatives of brusatol as anti-inflammatory agents: design, synthesis, biological evaluation, and nitric oxide release studies. J Med Chem. 2014;57(18):7600-12.

10. Zhu S, Liu S, Wang L, Ding W, Sha J, Qian H, et al. Brusatol Protects HepG2 Cells against OxygenGlucose Deprivation-Induced Injury via Inhibiting Mitochondrial Reactive Oxygen Species-Induced Oxidative Stress. Pharmacology. 2019:1-8.

11. Bu T, Wang $C$, Meng $Q$, Huo $X$, Sun $H$, Sun $P$, et al. Hepatoprotective effect of rhein against methotrexate-induced liver toxicity. Eur J Pharmacol. 2018;834:266-73.

12. Ren D, Villeneuve NF, Jiang T, Wu T, Lau A, Toppin $\mathrm{HA}$, et al. Brusatol enhances the efficacy of chemotherapy by inhibiting the Nrf2-mediated defense mechanism. Proc Natl Acad Sci U S A. 2011;108(4):1433-8.

13. Xiang Y, Ye W, Huang C, Yu D, Chen H, Deng T, et al. Brusatol Enhances the Chemotherapy Efficacy of Gemcitabine in Pancreatic Cancer via the Nrf2 Signalling Pathway. Oxid Med Cell Longev. 2018;2018:2360427.

14. Park SH, Kim JH, Ko E, Kim JY, Park MJ, Kim MJ, et al. Resistance to gefitinib and cross-resistance to irreversible EGFR-TKIs mediated by disruption of the Keap1-Nrf2 pathway in human lung cancer cells. Faseb J. 2018:fj201800011R.

15. Xiang Y, Ye W, Huang C, Lou B, Zhang J, Yu D, et al. Brusatol inhibits growth and induces apoptosis in pancreatic cancer cells via JNK/p38 MAPK/NFkappab/Stat3/Bcl-2 signaling pathway. Biochem Biophys Res Commun. 2017;487(4):820-6.

16. Meng QT, Chen R, Chen C, Su K, Li W, Tang LH, et al. Transcription factors Nrf2 and NF-kappaB contribute to inflammation and apoptosis induced by intestinal ischemia-reperfusion in mice. Int $\mathrm{J}$ Mol Med. 2017;40(6):1731-40.
17. Ohkawa H, Ohishi N, Yagi K. Assay for Lipid Peroxides in Animal-Tissues by Thiobarbituric Acid Reaction. Anal Biochem. 1979;95(2):351-8.

18. Harma $M$, Harma M, Kocyigit A, Erel O. Increased DNA damage in patients with complete hydatidiform mole. Mutat Res-Gen Tox En. 2005;583(1):49-54.

19. Bradley PP, Priebat DA, Christensen RD, Rothstein G. Measurement of cutaneous inflammation: estimation of neutrophil content with an enzyme marker. J Invest Dermatol. 1982;78(3):206-9.

20. Sun Y, Oberley LW, Li Y. A Simple Method for Clinical Assay of Superoxide-Dismutase. Clin Chem. 1988;34(3):497-500.

21. Singer $M$, Deutschman CS, Seymour CW, ShankarHari M, Annane D, Bauer $M$, et al. The Third International Consensus Definitions for Sepsis and Septic Shock (Sepsis-3). JAMA. 2016;315(8):801-10.

22. Sadowitz B, Roy S, Gatto LA, Habashi N, Nieman G. Lung injury induced by sepsis: lessons learned from large animal models and future directions for treatment. Expert Rev Anti Infect Ther. 2011;9(12):1169-78.

23. Rubenfeld GD, Caldwell E, Peabody E, Weaver J, Martin DP, Neff M, et al. Incidence and outcomes of acute lung injury. N Engl J Med. 2005;353(16):168593.

24. Maybauer MO, Maybauer DM, Herndon DN. Incidence and outcomes of acute lung injury. N Engl J Med. 2006;354(4):416-7.

25. Husak L, Marcuzzi A, Herring J, Wen E, Yin L, Capan $\mathrm{DD}$, et al. National analysis of sepsis hospitalizations and factors contributing to sepsis in-hospital mortality in Canada. Healthcare quarterly (Toronto, Ont). 2010;13:35-41.

26. Angus DC, Linde-Zwirble WT, Lidicker J, Clermont G, Carcillo J, Pinsky MR. Epidemiology of severe sepsis in the United States: analysis of incidence, outcome, and associated costs of care. Critical care medicine. 2001;29(7):1303-10. 
27. Hotchkiss RS, Karl IE. The pathophysiology and treatment of sepsis. N Engl J Med. 2003;348(2):13850.

28. Sandrock CE, Albertson TE. Controversies in the treatment of sepsis. Seminars in respiratory and critical care medicine. 2010;31(1):66-78.

29. Curley G, Hayes M, Laffey JG. Can 'permissive' hypercapnia modulate the severity of sepsisinduced ALI/ARDS? Critical care (London, England). 2011;15(2):212.

30. Bhatia M, Moochhala S. Role of inflammatory mediators in the pathophysiology of acute respiratory distress syndrome. J Pathol. 2004;202(2):145-56.

31. Swantek JL, Tsen MF, Cobb MH, Thomas JA. IL-1 receptor-associated kinase modulates host responsiveness to endotoxin. J Immunol. (Baltimore, Md : 1950). 2000;164(8):4301-6.

32. Lin HI, Chu SJ, Wang D, Feng NH. Pharmacological modulation of TNF production in macrophages. Journal of microbiology, immunology, and infection = Wei mian yu gan ran za zhi. 2004;37(1):8-15.

33. Alves-Filho JC, de Freitas A, Spiller F, Souto FO, Cunha FQ. The role of neutrophils in severe sepsis. Shock (Augusta, Ga). 2008;30 1:3-9.

34. Ayhan Tanyeli EE, Mustafa Can Guler, Saime Ozbek Sebin, Demet Celebi, Fatma Betul Ozgeris, Erdem Toktay. Investigation of biochemical and histopathological effects of tarantula cubensis D6 on lung tissue in cecal ligation and punctureinduced polymicrobial sepsis model in rats. Medicine Science. 2019;8:644-50.

35. Li S, Bao HG, Han L, Liu L, Wang X. Effects of adiponectin on mortality and its mechanism in a sepsis mouse model. J Invest Surg. 2012;25(4):2149.

36. Girotti AW. Lipid hydroperoxide generation, turnover, and effector action in biological systems. J Lipid Res. 1998;39(8):1529-42.
37. Qian H, Liu D. The time course of malondialdehyde production following impact injury to rat spinal cord as measured by microdialysis and high pressure liquid chromatography. Neurochemical research. 1997;22(10):1231-6.

38. Arosio B, Gagliano N, Fusaro LM, Parmeggiani L, Tagliabue J, Galetti P, et al. Aloe-Emodin quinone pretreatment reduces acute liver injury induced by carbon tetrachloride. Pharmacol Toxicol. 2000;87(5):229-33.

39. McCord JM. Oxygen-derived free radicals in postischemic tissue injury. $\mathrm{N}$ Engl $\mathrm{J}$ Med. 1985;312(3):159-63.

40. Chabot F, Mitchell JA, Gutteridge JM, Evans TW. Reactive oxygen species in acute lung injury. Eur Respir J. 1998;11(3):745-57.

41. Demirbilek S, Ersoy MO, Demirbilek S, Karaman A, Akin $M$, Bayraktar $M$, et al. Effects of polyenylphosphatidylcholine on cytokines, nitrite/ nitrate levels, antioxidant activity and lipid peroxidation in rats with sepsis. Intensive Care Med. 2004;30(10):1974-8.

42. Maier $\mathrm{S}$, Traeger $\mathrm{T}$, Entleutner $\mathrm{M}$, Westerholt $\mathrm{A}$, Kleist B, Huser N, et al. Cecal ligation and puncture versus colon ascendens stent peritonitis: two distinct animal models for polymicrobial sepsis. Shock (Augusta, Ga). 2004;21(6):505-11.

43. Hubbard WJ, Choudhry M, Schwacha MG, Kerby JD, Rue LW, 3rd, Bland KI, et al. Cecal ligation and puncture. Shock (Augusta, Ga). 2005;24:52-7.

44. Remick DG, Newcomb DE, Bolgos GL, Call DR. Comparison of the mortality and inflammatory response of two models of sepsis: lipopolysaccharide vs. cecal ligation and puncture. Shock (Augusta, Ga). 2000;13(2):110-6.

45. Evans JP, Winiarski BK, Sutton PA, Jones RP, Ressel L, Duckworth CA, et al. Correction: The Nrf2 inhibitor brusatol is a potent antitumour agent in an orthotopic mouse model of colorectal cancer. Oncotarget. 2019;10(6):685. 
46. Evans JP, Winiarski BK, Sutton PA, Jones RP, Ressel L, Duckworth CA, et al. Correction: The Nrf2 inhibitor brusatol is a potent antitumour agent in an orthotopic mouse model of colorectal cancer. Oncotarget. 2019;10(6):685.

47. Turpaev K, Krizhanovskii C, Wang X, Sargsyan $E$, Bergsten P, Welsh N. The protein synthesis inhibitor brusatol normalizes high-fat diet-induced glucose intolerance in male C57BL/6 mice: role of translation factor elF5A hypusination. FASEB journal : official publication of the Federation of American Societies for Experimental Biology. 2019;33(3):3510-22.
48. Zhou J, Wang T, Dou Y, Huang Y, Qu C, Gao J, et al. Brusatol ameliorates 2, 4, 6-trinitrobenzenesulfonic acid-induced experimental colitis in rats: Involvement of NF-kappaB pathway and NLRP3 inflammasome. Int Immunopharmacol. 2018;64:264-74.

49. Turpaev K, Welsh N. Brusatol inhibits the response of cultured beta-cells to pro-inflammatory cytokines in vitro. Biochem Biophys Res Commun. 2015;460(3):868-72. 